DOI: $10.20472 / T E .2015 .3 .3 .005$

\title{
ENTREPRENEURSHIP EDUCATION: A PANACEA FOR CURBING GRADUATE UNEMPLOYMENT IN NIGERIA
}

\author{
NGOZI NWABUFO, JOSHUA MAMMAN
}

\begin{abstract}
:
The biggest challenges of Nigeria today are youth unemployment. Nigeria, being the giant of Africa has the largest number of youths who are yet to be properly mobilized and empowered for gainful economic activities. This can only be tackled through entrepreneurship education which involves teaching and learning of the needed skills and knowledge that equip one to become self-reliant through being an effective and successful initiator, manager, innovator and risk bearer of business undertakings. Unemployed youths should be encouraged to acquire skills that will be applied to economic activities on graduation from requisite compulsory training while those who are still in school should be made to offer entrepreneurship courses that would prepare them to embark on small and medium-scale enterprises, which have significant roles to play in the development of any economy. Therefore, this paper discusses entrepreneurship education and unemployment reduction in Nigeria, problems facing entrepreneurship education and its graduate and ways of addressing this problem so that our national and human resources will be properly employed for economic emancipation, so as to turn our youths into job creators and not job seekers.
\end{abstract}

\section{Keywords:}

entrepreneurship, education, graduate, unemployment, curbing

JEL Classification: A23

\section{Authors:}

NGOZI NWABUFO, Kwara State University, Malete, Nigeria, Email: engozbibi@gmail.com JOSHUA MAMMAN, Kwara State, Nigeria, Email: joshua.mamman@kwasu.edu.ng

\section{Citation:}

NGOZI NWABUFO, JOSHUA MAMMAN (2015). Entrepreneurship education: a panacea for curbing graduate unemployment in Nigeria. International Journal of Teaching and Education, Vol. III(3), pp. 68-74., 10.20472/TE.2015.3.3.005 


\section{Introduction}

Entrepreneurship education involves teaching and learning of the needed skills and knowledge that equip one to become self-reliant through being an effective and successful initiator, manager, innovator and risk-bearer of business undertakings. Igbo (2009) supports the above meaning of entrepreneurship education when she says that such education should produce self-reliance, job creators and not job seekers, besides, it equips the individual for creative problem solving and innovation.

In entrepreneurship education, people already in business are retrained to enhance their management, record keeping ability, and the profitability of their business, while university graduates and school leavers are taught skills and empowered to start their own businesses whereas students who are still in schools are trained to take their fate in their hands and to become entrepreneurs even right in schools.

Entrepreneurship in Nigeria is necessary for the country to become a developed nation. Nigeria has human resources who should be capable of retrieving, processing and utilizing her natural resources for the general well being of her citizens and development of her economy, given that they have appropriate skills. For these needed skills to be acquired, emphases should be directed towards entrepreneurship education which serves as a strategy for transforming the Nigeria economy in to one of the twenty largest economics in the world by the year 2020. This high rating which we want Nigeria economy to attain in the next five years can not be possible at the present low level of unemployment

Presently, youths' unemployment is very high in Nigeria with its attendant social vices such as kidnapping, arm robbery, prostitution and hired assassination and so on. In view of this, Nigerian youths should be re-oriented to embrace entrepreneurship in order to create more employment opportunities. Entrepreneurship education equips graduates with the right skills that will enable them to engage in a life of work in the office as well as for self employment and job creation for others. Nigerian Youths need to go beyond being educated. They should be exposed to skills acquisition in order to prepare them for life after school.

According to Ibeneme, (2009), Nigeria needs workforces that have the right skills, knowledge and attitudes of the workplace in order to develop industrially. The workforce being referred to here comes from the products of entrepreneurship education which is the master key that can alleviate poverty, promote peace and improve the quality of life for all.

\section{Who is an entrepreneur?}

Kindersley, (1998) defined an entrepreneur as an agent who unites all means of production by employing capital, labor, and land to produce goods and services that appeal to consumers and from which he gets his profits. Walker, (1946), in Kindersley, (1998) has a similar view by saying that entrepreneurs are engineers of industrial progress and chief agents of production. This view means that entrepreneurs initiate business ideas by taking the risk that is involved, bearing uncertainty in the course of transforming their ideas into finished products that appeal to end users and from which he gets his incomes as profits. Thus, an entrepreneur is characterized by vision , creativity, vitality, confidence to act on new opportunities, adaptability to altered conditions and most of all, the ability to imitate and implement change through innovation and implementation (Akapomi, 2010) 


\section{What is entrepreneurship?}

Entrepreneurship is the willingness and ability of an individual to seek out investment opportunities in an environment and be able to establish and run an enterprise successfully based on the indentified opportunities so as to meet the ever changing needs of the society, (Gana, 2001, as cited by Onwuegbune 2009)

According to Watson, (2011) entrepreneurship is a process through which individuals identify opportunities of un-met needs or change, allocate resources and create value through solutions. This idea implies that problems are seen by entrepreneurs as opportunities to take strategic and innovating business decisions to initiate, maintain, or aggrandize (increase in wealth) a profit oriented business unit. Igbo, (2009) defines entrepreneurship as the process of planning and organizing a small business venture, through the use of resources to create, develop and implement solution to problems, to meet people's need. In view of the above, entrepreneurship through small and medium scale industries will help to transform the economy from a dependent one to a viable and independent economy.

\section{Concept of Education}

Gillett (1969), defines education as a cultural process through which a society ensures that necessary and desirable knowledge, skills, attitudes and values are perpetuated through teaching and learning processes. From the above, it can be deduced that education involves transmission of culture, and the formation of personality as well as the changing of behavior to socially-approved direction.

\section{What is entrepreneurship Education?}

Cope, (2003) emphasized the need to institute an educational frame-work in Nigeria within which small and medium scale enterprise development can occur. This according to him can be achieved through entrepreneurship education.

Entrepreneurship education therefore, involves teaching and learning of the needed skills and knowledge that equip one to become self-reliant through being an effective and successful initiator, manager, innovator, and risk-bearer of business undertaking. In entrepreneurship education, people already in businesses are retrained to enhance their management, record keeping ability and the profitability of their businesses while unemployed university graduates and secondary schools leavers are taught skills in the schools and are trained to take their fate in their hands and to become entrepreneurs even right in the schools, (CEDR, 2008). Thus, Akpomi (2010) says that entrepreneurship education develops human abilities and changes their values and attitudes in order to accelerate the process of development. She went further to say that this type of education helps individuals to innovate and foresee the future needs arising from new ways of thinking.

\section{Entrepreneurship Education and its Curriculum}

According to Soludo (2006), over one hundred Tertiary Institutions in our country are producing more than two hundred thousand graduates per annum. This is the evidence that the basic human capital for economic transformation of our country is available for training and development to enable them provide solution to our economic problems. These graduates need to be nurtured on developing business ideas and risk taking so that the fear of venturing into new areas of businesses or starting something on their own will be wiped off their faces. They will learn to lead 
business combination of different sizes. According to CEDR, (2008) there is no education degree requirement to become an entrepreneur, but it is helpful to have, good support skills such as communication, Interpersonal abilities, economic understanding, digital skills, marketing, management and fiancial skills.

Therefore, a would be entrepreneur, should be prepared on the following areas, (Cope, 2003).

a. Entrepreneurship development: this involves exposing the learners to develop business ideas, identify business opportunities and risk taking behavior. Emphasis should be on taking calculated risk which allows for reasonable profits and minimal chances of losing one's investment. He further learns how to become innovative, resourcefulness, and task oriented.

b. Basic Business Management: The prospective entrepreneur learns how to run and control business. In this direction he is exposed to business planning and management. For instance, he should learn about financial planning, effective communication, decision making, time management business negotiation skills, credit management, record keeping, leadership, interpersonal skills, conflict handling and customer loyalty.

c. Skill Acquisition: Enterprising men and women should have the practical skill that enables them to undertake and complete activities. The following skills among others should be taught, Agro production such as fish farming, poultry management, piggery management, snail and mushroom farming. In cosmetology, making of the following and others should be taught; soap, cream, paint, tooth paste, shoe polish and air freshener. Under Information, communication and technology, the following skills should be taught: computer maintenance, software applications, computer networking, and intercom networking. In creative arts and design, the following skills are necessary; Shoe and bag making fashion designing, hat and bead making. Furthermore, productions of brake pads from saw dust and grease from palm oil should be taught. In service based business, travelling and courier agencies, marketing, clearing and forwarding and auto mechanics should taught while in food and catering services, attention should be given to hotel management, ice cream production and packaging. Skills in book binding, graphic designing, recharge card printing and others should be taught under printing and publishing. Other trades such as welding and fabrication, electrical/electronic, refrigeration, air conditioning and plumbing are also worthy of consideration.

\section{Entrepreneurship education and unemployment reduction}

Obasanjo, (2003) says that human development will be grossly undermined and impaired without employment. To avoid this situation, there is need to promote small and medium scale enterprises through entrepreneurship education which prepares individuals by ways of skills and knowledge acquisition that empower them to set up productive ventures that engage the entrepreneurs and others thereby reducing unemployment and poverty which has many manifestations and dimensions in Nigeria, such as joblessness, over indebtedness economic dependency, lack of freedom, inability to provide the basic needs of life for self and family, lack of access to land and credit and inability to save and own assets (investments)

According to Soludo (2009) our country has a new economic order which is embodied in Obansanjo;s socio-economic transformation agenda entitled :National Economic 
Empowerment and Development Strategy (NEEDS), which has four key objectives as follows; poverty reduction, employment generation, wealth creation, and value reorientation. For these objectives to be achieved, entrepreneurship education, has to be effectively implemented

Its adoption and adaptation will go a long way to transform the Nigeria economy since individuals are taught different skills that empower them to become job creators, venturing into and modified areas of productive activities as already mentioned.

In Singapore, the unemployment situation has reduced because people find it less difficult to be gainfully employed after getting vocational training which is compulsory for every secondary school leaver, (Loh, 2011)

Thus, for Nigeria to sustain her economic growth there is need to develop the human resources through technical, vocational and entrepreneurship education. If possible the Singaporean model of compulsory nationals skills acquisition program after secondary school education should be adopted to enable our abundant human capital acquire the relevant skills, knowledge and values responsive to the changing needs of school leavers, industry and community for sustainability and national development, Our youths need to be equipped with skills that are required to operate successful businesses .Technical skills are expected to be supported by entrepreneurial skills to be able to succeed in any business. Therefore, let the graduates tertiary institutions in our country be mobilized for skills acquisition and entrepreneurial development to enable them embark on small and medium scale enterprises which are the largest employers of labor at the lowest cost in developed nations.

\section{Problems facing entrepreneurship Education and its Graduates in Nigeria}

Funding in this type of education, which needs costly machines and equipment for proper acquisition of skills and knowledge to take place is one of the greatest problemss.

Poor financial status of our graduates is another stumbling block to development of business ideas. Access to business capital to fiancé entrepreneurial endeavor in Nigeria is very difficult because of political and economic instability. Constant political turmoil in the country greatly limits foreign investors who would be willing to provide resources for entrepreneurship in Nigeria.

Again, technical instructors and supporting staff that are needed for imparting of skills and knowledge are inadequate when compared with the population of unemployed youths in Nigeria.

Also writing a good business plan on graduation that will attract credit support from financial industry is a real problem facing the graduates of entrepreneurship education in Nigeria.

Finally, the poor infrastructural facilities in Nigeria such as the epileptic supply of electricity and road network are barriers to entrepreneurial effectiveness and success in Nigeria.

\section{Conclusion}

Entrepreneurship education as a means to an end and a road map towards reduction of unemployment and poverty levels should be pursued with every vigor so that its 
objectives of overall economic transformation will be attained. To this regard, our educational system should be channeled to skills acquisition and entrepreneurial training which would engender mass job creators and not youths searching for whitecollar jobs. Our youths should be equipped with entrepreneurial skills to enable them operate successful businesses.

\section{Recommendations:}

Below are some recommendations for addressing the problems facing entrepreneurship education and its graduates in Nigeria.

* Nigeria's education system should be revived to give credence to entrepreneurship education. School curricula need urgent review to make them relevant and practice oriented. The present system that emphasizes theoretical knowledge for white collar-jobs at the expenses of technical, vocational and entrepreneurial education should be jettisoned for an efficient, relevant and functional education to operate.

* The present one year for compulsory National Youth Service on graduation should be changed to one year compulsory training on entrepreneurship, vocational and technical education. If this is done, our tertiary institution graduates will no more be dependent on white collar jobs rather they will be independent for self reliance and self employment that will transform into economic emancipation at the long run.

* There should be provision of enabling environment for graduates of entrepreneurship, vocational and technical education to operate in. In this regard, good road network is required for our hinterland, likewise constant supply of electricity and water. These facilities will encourage the entrepreneurs to make rural areas their bases thereby reducing urban congestion.

* A strong legal institution framework is the key to economic transformation. There must be respect for the rule of law and not rule of men. Law helps to unlock human potentials by fashioning a society based on individual freedoms, competition and private enterprises, (Soludo, 2006). Therefore, wherever the rule of law prevails and property right and contract enforcements are more effective, progress and economic transformation will be faster than where such conditions are absent

* Security of life and property is necessary for any venture to operate and thrive. Ethnic and national conflicts should be resolved to enable new enterprises be set up in every nook and cranny of the country

* Government should empower graduates of entrepreneurship education in the direction of credit facility, site acquisition for establishment of their enterprises, equipment and machines for the take off, extension services and gestation period of five years to repay any loan given to them to ensure mastery, stability and growth.

* More funds should be budgeted by government for technical, vocational and entrepreneurship education so that the youths should be developed to face the challenges of the changing world of work with the acquired skills, knowledge, and values for life-long learning and self-help.

* Government should partner with private sectors, industries, civil society, ,organizations and communities to get funding for the procurement of equipment and workshops. This will make a quick way for the technical, vocational and entrepreneurship education. 
* Graduates of entrepreneurship education should form cooperatives to enable them access credit facilities easily to develop their ideas, while government should on her own part patronize these cooperatives when awarding contracts as a way of encouraging them to grow.

* Skills Training Centers (STC) which are in form of Post Secondary Technical Training Institutes should be established in every local government area for school leavers and adult learners to acquire employable skills, knowledge and values needed in a competitive global economy and for self employment for onward poverty reduction

* Enough instructors and supporting staff should be recruited and trained for the take-off of entrepreneurship education in Nigeria.

* Finally, graduates of entrepreneurship education should be properly guided in writing an acceptable business plan that will be attractive to investors for sponsorship

\section{References}

Adeoba, O. (april 5, 2011). Tackling unemployment through entrepreneurial Skills: the Guardian, Tuesday, P.37

Akpomi, M.E, (2010). Preparedness of National Youth Service Corps Members in South-South Nigeria for entrepreneurship, Business Education journal: vii (2) 226

Arthur, A.T, Strickland, A.J (1978), Strategic Management, concepts and cases, Texas: Business publication Inc.

Atta, D. (August 2, 2011). Banker task youths on entrepreneurship, The Guardian, Tuesday, P.42

Centre for entrepreneurship and Development research, (2008) Students class Album: South East Zone, Onitsha.

Cope, J. (2003). Entrepreneurial learning and critical reflection: Discontinuous events are triggers for higher level learning: Management learning 34 (4) 429-450.

Gillett, M (1969): Reading in the history of education, Canada: McGraw Hill lbeneme, O.T (2009). Vocational Education in the era of economic downturn

Vis-avis vision 2020 in Nigeria, Journal of vocational and technical education: 7 (1) 10.

Igbo, C.A, (2009). Vision 2020, Challenges for entrepreneurship in Vocational Education and enhancement strategies, journal of vocational and technical education. 7 (1) 20

Kindersley, D. (1998). Illustrated Oxford Dictionary, London: Oxford University Press.

Ojechi, H.O (2011) Entrepreneurship education: A strategy for solving unemployment problem in Nigeria Unpublished journal article presented at the $5^{\text {th }}$ Bi-ennial National conference on Vocation Education and employment in Nigeria school of vocation education, college of Education Warri, Delta State Nigeria.

Loh. K.F (June 9, 2011) Nigeria Adopts Singaporean model in national skills acquisition programmer, the Guardian: Thursday, p.29.

National Planning Commission: (2004) National Economic Empowerment and Development Strategy (NEEDS); Abuja; Communication Development Incorporated.

Obasanjo, O. (2003). NEEDS: Measuring the quality of life, Abuja National Planning Commission 